\title{
Effect of Time-Resolution of Rainfall Data on Trend Estimation for Annual Maximum Depths with a Duration of 24 Hours
}

\author{
Renato Morbidelli $^{1, *(\mathbb{D})}$, Carla Saltalippi ${ }^{1}\left(\mathbb{D}\right.$, Jacopo Dari $^{1,2}{ }^{10}$ and Alessia Flammini ${ }^{1}(\mathbb{D}$ \\ 1 Department of Civil and Environmental Engineering, University of Perugia, via G. Duranti 93, \\ 06125 Perugia, Italy; carla.saltalippi@unipg.it (C.S.); jacopo.dari@unipg.it (J.D.); \\ alessia.flammini@unipg.it (A.F.) \\ 2 National Research Council, Research Institute for Geo-Hydrological Protection, via Madonna Alta 126, \\ 06128 Perugia, Italy \\ * Correspondence: renato.morbidelli@unipg.it; Tel.: +39-075-5853620
}

check for updates

Citation: Morbidelli, R.; Saltalippi, C.; Dari, J.; Flammini, A. Effect of Time-Resolution of Rainfall Data on Trend Estimation for Annual Maximum Depths with a Duration of 24 Hours. Water 2021, 13, 3264. https://doi.org/10.3390/w13223264

Academic Editor: Ataur Rahman

Received: 11 October 2021

Accepted: 16 November 2021

Published: 17 November 2021

Publisher's Note: MDPI stays neutral with regard to jurisdictional claims in published maps and institutional affiliations.

Copyright: (c) 2021 by the authors. Licensee MDPI, Basel, Switzerland. This article is an open access article distributed under the terms and conditions of the Creative Commons Attribution (CC BY) license (https:// creativecommons.org/licenses/by/ $4.0 /)$.

\begin{abstract}
The main challenge of this paper is to demonstrate that one of the most frequently conducted analyses in the climate change field could be affected by significant errors, due to the use of rainfall data characterized by coarse time-resolution. In fact, in the scientific literature, there are many studies to verify the possible impacts of climate change on extreme rainfall, and particularly on annual maximum rainfall depths, $H_{d}$, characterized by duration $d$ equal to $24 \mathrm{~h}$, due to the significant length of the corresponding series. Typically, these studies do not specify the temporal aggregation, $t_{a}$, of the rainfall data on which maxima rely, although it is well known that the use of rainfall data with coarse $t_{a}$ can lead to significant underestimates of $H_{d}$. The effect of $t_{a}$ on the estimation of trends in annual maximum depths with $d=24 \mathrm{~h}, H_{d=24}$, over the last 100 years is examined. We have used a published series of $H_{d=24} h$ derived by long-term historical rainfall observations with various temporal aggregations, due to the progress of recording systems through time, at 39 representative meteorological stations located in an inland region of Central Italy. Then, by using a recently developed mathematical relation between average underestimation error and the ratio $t_{a} / d$, each $H_{d=24} h$ value has been corrected. Successively, commonly used climatic trend tests based on different approaches, including least-squares linear trend analysis, Mann-Kendall, and Sen's method, have been applied to the "uncorrected" and "corrected" series. The results show that the underestimation of $H_{d=24} h$ values with coarse $t_{a}$ plays a significant role in the analysis of the effects of climatic change on extreme rainfalls. Specifically, the correction of the $H_{d=24} h$ values can change the sign of the trend from positive to negative. Furthermore, it has been observed that the innovative Sen's method (based on a graphical approach) is less sensitive to corrections of the $H_{d}$ values than the least-squares linear trend and the Mann-Kendall method. In any case, the analysis of $H_{d}$ series containing potentially underestimated values, especially when $d=24 \mathrm{~h}$, can lead to misleading results. Therefore, before conducting any trend analysis, $H_{d}$ values determined from rainfall data characterized by coarse temporal resolution should always be corrected.
\end{abstract}

Keywords: rainfall data measurements; rainfall time resolution; extreme rainfall; annual maximum rainfall depths; trend analysis

\section{Introduction}

It is well known that climate change is mainly due to greenhouse gas emissions from human activities [1]. One of the most important consequences is the modification of the hydrologic cycle with significant implications for water resources [2-5]. In the last century, mean global surface temperatures showed an increase of approximately $1.1^{\circ} \mathrm{C}$ [6] and, based on the Clausius-Clapeyron relation, for each $1^{\circ} \mathrm{C}$ increase in global temperature, the precipitable water increases by $\sim 7 \%[7,8]$, even though relative humidity appears to decrease at high temperatures [1,8-10]. Moreover, it is expected that temperature will increase near to the surface and will decrease in the upper troposphere, favoring 
atmospheric instability [11]. Considering that atmospheric warming and water vapor trends also have local non-uniformity, the associated variation in average rainfall is typically mutable over the planet [12].

Extreme precipitation is very erratic, and its trends are less spatially coherent than those in average rainfall. On a global scale, there are significant unevenness and places where heavy rainfall is increasing, seemingly prevailing over areas where they are decreasing [13]. For example, [14] evaluated the long-term (1950-2018) trends in daily precipitation extremes over more than 7000 stations, and found that $66 \%$ of them showed increasing trends, and the remaining $34 \%$ showed decreasing trends. Furthermore, approximately $10 \%$ of stations (mainly in Europe, North America, and South Africa) showed a statistically significant increasing trend, while only $2.1 \%$ of stations (in the western United States, Canadian Prairies, and northern China) showed a significant decreasing trend. Reference [15] studied changes in daily precipitation over the Australian continent (period 1966-2013). They found an increase in daily precipitation during the second half of the observed period, as compared to the first half. Considering the period 1950-2015 and using daily gridded rainfall data (at 0.25-degree spatial resolution), [16] showed a significant rise in extreme precipitation events over central India. Increasing daily rainfall trends have been found also in west China [17], Bangladesh [18], South Korea [19], southern west Africa [20], and parts of southeast Asia [21].

Clear evidence that temporal variations in the occurrence of extreme rainfall events can be due to large-scale atmospheric and oceanographic oscillations, such as the North Atlantic Oscillation (NAO) or El Niño-Southern Oscillation (ENSO), is described in the scientific literature (e.g., [22-30]). Indicative analysis by [31] showed cyclic variations with a period of 30-40 years, and concluded that trends over time periods of $<40$ years could be ascribed to large-scale atmospheric changes.

Therefore, the analysis of trends in annual maximum rainfall depths, $H_{d}$, for a given duration, $d$, should be performed only for long-term rainfall data recorded, for example, from the earliest decades of the last century (see also [32]). Furthermore, analyses on the $H_{d}$ series for $d<1 \mathrm{~h}$ are rarely available since, in the last century, all rainfall data have been recorded by adopting different temporal aggregations (or time resolutions), $t_{a}$, dependent on changes in the recording systems through time. Currently, rainfall amounts are measured by tipping bucket sensors and recorded in a data-logger for each tip-time associated with a fixed rainfall depth, but until the last decades of the 21st century they were recorded only over paper rolls (pluviograph), generally with hourly $t_{a}[33,34]$. In addition, for many years, especially before the Second World War, only daily rainfalls are available, recorded daily at a specific local time, and measuring the accumulated depth during the previous $24 \mathrm{~h} \mathrm{[35].}$

On this basis it can be deduced that, before the advent of data-loggers, rainfall data were always characterized by coarse temporal aggregation, with probable effects on analyses based on their use [36-47]. In fact, in some cases, the correct values of $H_{d}$ can be significantly underestimated up to $50 \%$, especially when $d=1 \mathrm{~h}$ and $24 \mathrm{~h}$, due to the high probability of the presence of values with $t_{a} / d=1$ [48]. Moreover, long series of $H_{d}$ values, together with a percentage of values obtained from continuous data (more recently recorded), always contain a percentage of elements derived from data characterized by coarse temporal aggregation, that are therefore potentially underestimated. This is problematic since, as well as the replacement of stations, the use of various rain gauge types with time and the change of surrounding near the equipment, could produce important effects on associated analyses, including the determination of rainfall depth-intensity-frequency curves [47] and trend evaluation of intense rainfalls [48].

By using some of the more common climatic trend tests characterized by very different approaches (least-squares linear trend analysis, Mann-Kendall test, and Sen's method) the main objective of this paper is to evaluate the effect of time-resolution of rainfall data on trend estimation for annual maximum depths with duration $24 \mathrm{~h}$. We focus our attention on the $H_{d}$ series with $d=24 \mathrm{~h}$ as they are among the longest and most frequently available 
series for analyses of climate trends. However, similar analyses could be carried out for different $d$.

Furthermore, another significant challenge that we launch with this paper, together with the special issue that we promoted, consists in stimulating similar analyses conducted in different geographical areas of the world.

\section{Study Area and Rainfall Data}

The study area (Umbria region, with a surface area of $8456 \mathrm{~km}^{2}$ ) is located in an inland zone of central Italy, and is characterized by a complex orography along the eastern boundary, where the Apennine Mountains exceed $2000 \mathrm{~m}$ a.s.l. In the central and western areas, orography is mainly of hilly type, with elevations ranging from 100 to $800 \mathrm{~m}$ a.s.1.. A wide percentage of the study area is included in the basin of Tiber River that crosses the region from north to south-west receiving water from many tributaries, mainly located on the hydrographic left side.

On the basis of observations made by the rain gauge network shown in Figure 1 and specified in Table 1, annual rainfall depth through the region ranges from $650 \mathrm{~mm}$ to $1450 \mathrm{~mm}$, with mean value of about $900 \mathrm{~mm}$. Higher monthly rainfall values generally occur during the autumn-winter period, with floods caused by widespread rainfall.
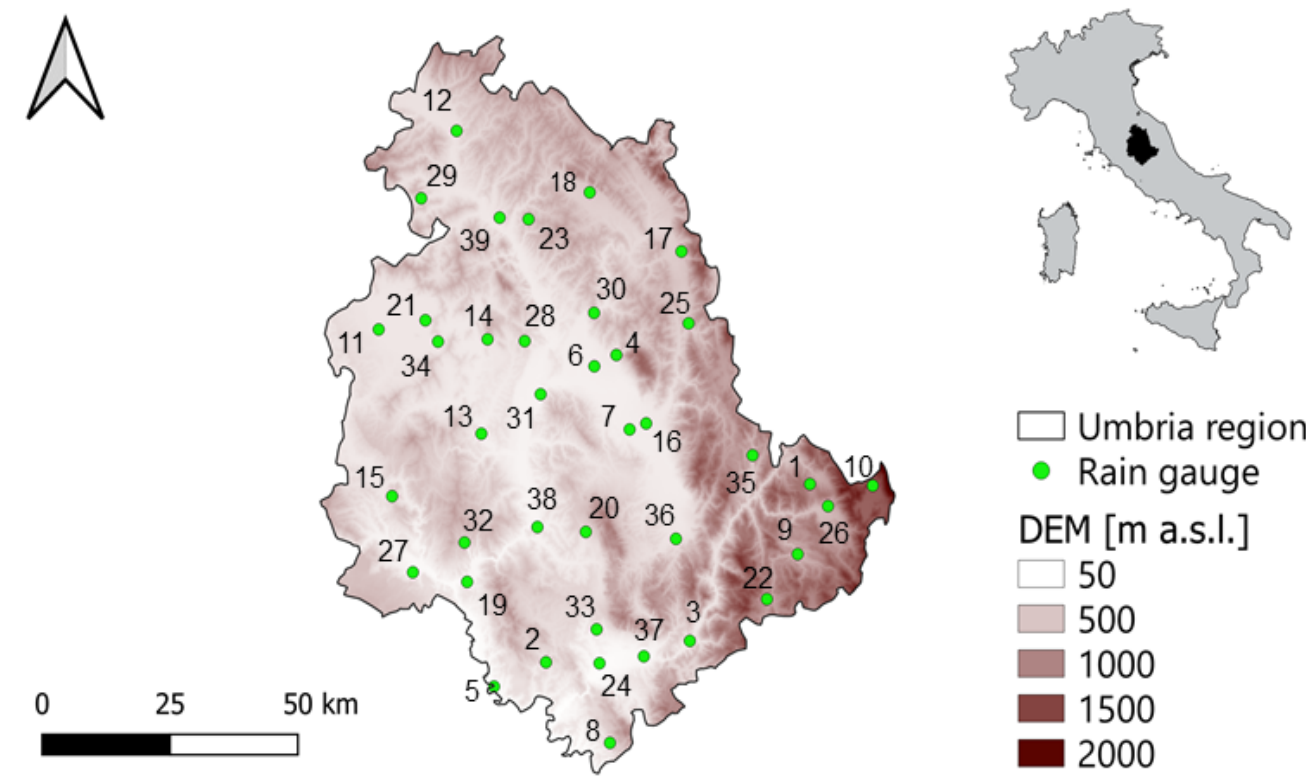

Figure 1. Morphology of the study area and rain gauges used in the analysis with identification numbers listed in Table 1. The background Digital Elevation Model (DEM), whose spatial resolution is $25 \mathrm{~m}$, is derived by the Copernicus EU-DEM v1.1.

Table 1. Main characteristics of the selected rainfall stations. The geographic position is expressed in Universal Transvers Mercator (UTM) coordinates computed by using the WGS84 ellipsoid model. ARD $\mathrm{Ata}_{\text {ta }}$ is the percentage of available rainfall data characterized by specific temporal aggregation, $t_{a}$.

\begin{tabular}{|c|c|c|c|c|c|c|c|c|}
\hline \multirow{2}{*}{$\begin{array}{c}\text { ID } \\
\text { Number }\end{array}$} & \multirow{2}{*}{$\begin{array}{l}\text { Rain Gauge } \\
\text { Station }\end{array}$} & \multirow{2}{*}{$\begin{array}{l}\text { Altitude } \\
\text { (m a.s.l.) }\end{array}$} & \multirow{2}{*}{$\begin{array}{c}\text { UTM33 X } \\
\text { (m) }\end{array}$} & \multirow{2}{*}{$\begin{array}{c}\text { UTM33 Y } \\
\text { (m) }\end{array}$} & \multirow{2}{*}{$\begin{array}{c}\text { Available } \\
\text { Data Period }\end{array}$} & \multicolumn{3}{|c|}{$\operatorname{ARD}_{\text {ta }}(\%)$} \\
\hline & & & & & & $t_{a}=1 \mathrm{~min}$ & $t_{a}=60 \mathrm{~min}$ & $t_{a}=1440 \mathrm{~min}$ \\
\hline 1 & Abeto & 946 & 341,805 & $4,744,571$ & 1951-2014 & 9.4 & 0.0 & 90.6 \\
\hline 2 & Amelia & 321 & 287,959 & $4,714,829$ & 1921-2017 & 19.2 & 20.5 & 60.3 \\
\hline 3 & Arrone & 221 & 316,289 & $4,716,860$ & $1921-2017$ & 11.0 & 0.0 & 89.0 \\
\hline 4 & Assisi & 408 & 305,799 & $4,771,442$ & 1921-2001 & 0.0 & 45.2 & 54.8 \\
\hline 5 & Attigliano & 64 & 277,495 & $4,711,022$ & $1921-2015$ & 11.8 & 0.0 & 88.2 \\
\hline 6 & Bastia & 203 & 301,377 & $4,769,716$ & $1922-2017$ & 31.8 & 0.0 & 68.2 \\
\hline 7 & Bevagna & 212 & 307,370 & $4,757,320$ & 1921-2017 & 21.7 & 6.0 & 72.3 \\
\hline 8 & $\begin{array}{c}\text { Calvi } \\
\text { dell'Umbria }\end{array}$ & 305 & 299,164 & $4,698,561$ & 1951-2017 & 20.4 & 0.0 & 79.6 \\
\hline
\end{tabular}


Table 1. Cont.

\begin{tabular}{|c|c|c|c|c|c|c|c|c|}
\hline \multirow{2}{*}{$\begin{array}{c}\text { ID } \\
\text { Number }\end{array}$} & \multirow{2}{*}{$\begin{array}{l}\text { Rain Gauge } \\
\text { Station }\end{array}$} & \multirow{2}{*}{$\begin{array}{l}\text { Altitude } \\
\text { (m a.s.l.) }\end{array}$} & \multirow{2}{*}{$\begin{array}{l}\text { UTM33 X } \\
\text { (m) }\end{array}$} & \multirow{2}{*}{$\begin{array}{c}\text { UTM33 Y } \\
\text { (m) }\end{array}$} & \multirow{2}{*}{$\begin{array}{l}\text { Available } \\
\text { Data Period }\end{array}$} & \multicolumn{3}{|c|}{$\mathrm{ARD}_{\mathrm{ta}}(\%)$} \\
\hline & & & & & & $t_{a}=1 \mathrm{~min}$ & $t_{a}=60 \mathrm{~min}$ & $t_{a}=1440 \mathrm{~min}$ \\
\hline 9 & Cascia & 604 & 338,477 & $4,731,592$ & 1922-2017 & 19.6 & 0.0 & 80.4 \\
\hline 10 & $\begin{array}{c}\text { Castelluccio di } \\
\text { Norcia }\end{array}$ & 1349 & 354,031 & $4,743,409$ & 1921-2017 & 12.7 & 0.0 & 87.3 \\
\hline 11 & $\begin{array}{c}\text { Castiglione } \\
\text { del Lago }\end{array}$ & 260 & 259,760 & $4,779,579$ & 1921-2019 & 15.7 & 27.1 & 57.1 \\
\hline 12 & $\begin{array}{l}\text { Città di } \\
\text { Castello }\end{array}$ & 304 & 277,643 & $4,815,738$ & 1921-2019 & 36.4 & 29.9 & 33.8 \\
\hline 13 & Compignano & 240 & 278,394 & $4,758,593$ & 1922-2017 & 34.6 & 0.0 & 65.4 \\
\hline 14 & Corciano & 306 & 280,871 & $4,776,204$ & 1921-2019 & 16.4 & 0.0 & 83.6 \\
\hline 15 & Ficulle & 440 & 260,144 & $4,747,480$ & 1921-2015 & 10.8 & 0.0 & 89.2 \\
\hline 16 & Foligno & 220 & 310,678 & $4,758,225$ & 1916-2015 & 25.7 & 31.4 & 42.9 \\
\hline 17 & Gualdo Tadino & 599 & 319,870 & $4,789,953$ & 1921-2019 & 18.4 & 47.1 & 34.5 \\
\hline 18 & Gubbio & 471 & 302,789 & $4,802,329$ & 1921-2019 & 20.0 & 42.5 & 37.5 \\
\hline 19 & $\begin{array}{l}\text { Lago di } \\
\text { Corbara }\end{array}$ & 128 & 273,640 & $4,731,014$ & 1963-2019 & 34.0 & 0.0 & 66.0 \\
\hline 20 & $\begin{array}{c}\text { Massa } \\
\text { Martana }\end{array}$ & 328 & 297,457 & $4,738,741$ & 1921-2019 & 24.6 & 4.9 & 70.5 \\
\hline 21 & $\begin{array}{c}\text { Monte del } \\
\text { Lago }\end{array}$ & 260 & 270,657 & $4,780,252$ & 1923-2016 & 12.5 & 36.3 & 51.3 \\
\hline 22 & $\begin{array}{l}\text { Monteleone di } \\
\text { Spoleto }\end{array}$ & 933 & 331,882 & $4,723,618$ & 1953-2019 & 23.7 & 0.0 & 76.3 \\
\hline 23 & Montelovesco & 634 & 290,484 & $4,798,142$ & 1921-2019 & 41.2 & 0.0 & 58.8 \\
\hline 24 & Narni Scalo & 109 & 298,381 & $4,713,916$ & 1921-2019 & 33.7 & 0.0 & 66.3 \\
\hline 25 & $\begin{array}{l}\text { Nocera } \\
\text { Umbra }\end{array}$ & 534 & 320,281 & $4,776,405$ & 1921-2019 & 32.6 & 0.0 & 67.4 \\
\hline 26 & Norcia & 691 & 345,042 & $4,740,189$ & 1921-2019 & 24.4 & 0.0 & 75.6 \\
\hline 27 & Orvieto & 311 & 263,178 & $4,733,559$ & 1921-2015 & 21.3 & 46.1 & 32.6 \\
\hline 28 & Perugia & 440 & 288,087 & $4,775,349$ & 1921-2019 & 3.8 & 43.8 & 52.5 \\
\hline 29 & Petrelle & 342 & 269,830 & $4,803,553$ & 1921-2019 & 30.4 & 0.0 & 69.6 \\
\hline 30 & Pianello & 233 & 302,003 & $4,779,669$ & 1921-2019 & 22.6 & 0.0 & 77.4 \\
\hline 31 & Ponte Nuovo & 174 & 290,491 & $4,765,144$ & 1921-2019 & 21.7 & 7.2 & 71.1 \\
\hline 32 & Prodo & 431 & 273,752 & $4,738,790$ & 1921-2017 & 13.6 & 0.0 & 86.4 \\
\hline 33 & San Gemini & 299 & 298,275 & $4,720,301$ & 1921-2019 & 19.5 & 6.9 & 73.6 \\
\hline 34 & San Savino & 260 & 271,170 & $4,776,468$ & 1921-2018 & 32.0 & 0.0 & 68.0 \\
\hline 35 & Sellano & 604 & 330,307 & $4,750,480$ & 1951-2017 & 32.4 & 0.0 & 67.6 \\
\hline 36 & Spoleto & 353 & 314,952 & $4,736,162$ & 1921-2019 & 20.7 & 40.2 & 39.1 \\
\hline 37 & Terni & 123 & 307,123 & $4,714,603$ & 1921-2019 & 18.4 & 32.2 & 49.4 \\
\hline 38 & Todi & 329 & 288,089 & $4,740,319$ & 1921-2019 & 29.8 & 40.4 & 29.8 \\
\hline 39 & Umbertide & 305 & 284,867 & $4,798,836$ & 1921-2019 & 22.5 & 28.8 & 48.8 \\
\hline
\end{tabular}

For each selected station, we considered all the $H_{d=24} h$ values already obtained and validated from the Regional Hydrographic Service (RHS) by using the available rainfall data. It is important to note that recently, mainly since 1992, it has been possible to obtain rainfall data recorded in data-loggers for each tip time associated with a fixed rainfall depth (no more than $0.2 \mathrm{~mm}$ ). In this case, each rainfall event was summarized by aggregating the number of tips over a $t_{a}$ equal to $1 \mathrm{~min}$. Nevertheless, for long time series, a considerable amount of rainfall data was available with hourly recording system, as a consequence of the paper rolls adoption. Furthermore, in the absence of other possibilities, daily information derived from direct observation made each day at 9:00 a.m. was used. Two examples of the $H_{d=24} h$ series used in this paper are shown in Tables 2 and 3 for the Gubbio and Todi rain gauge stations, respectively. For all analyses carried out in this paper, $39 \mathrm{H}_{d=24 h}$ time series for the rain gauge stations reported in Table 1 were selected. 
Table 2. Annual maximum rainfall depths (in $\mathrm{mm}$ ) for duration (d) equal to $24 \mathrm{~h}, H_{d=24}$, derived from data characterized by different aggregation times, $t_{a}$. Gubbio rain gauge station.

\begin{tabular}{cccccccc}
\hline Year & $\boldsymbol{H}_{\boldsymbol{d}=\mathbf{2 4} \boldsymbol{h}}$ & Year & $\boldsymbol{H}_{\boldsymbol{d}=\mathbf{2 4} \boldsymbol{h}}$ & Year & $\boldsymbol{H}_{\boldsymbol{d}=\mathbf{2 4} \boldsymbol{h}}$ & Year & $\boldsymbol{H}_{\boldsymbol{d}=\mathbf{2 4} \boldsymbol{h}}$ \\
\hline 1921 & 65 & 1944 & 58.2 & 1973 & 43.4 & 1997 & 76.7 \\
1922 & 49 & 1946 & 72 & 1974 & 40.4 & 1998 & 62.7 \\
1923 & 55.6 & 1947 & 55 & 1975 & 89.8 & 1999 & 70.4 \\
1924 & 45 & 1948 & 61 & 1976 & 72.4 & 2000 & 63 \\
1925 & 48 & 1949 & 58 & 1977 & 40 & 2001 & 51.5 \\
1926 & 56.4 & 1950 & 31.7 & 1978 & 54.2 & 2002 & 52.6 \\
1927 & 34.2 & 1951 & 61 & 1979 & 53.4 & 2003 & 106.8 \\
1928 & 55.7 & 1952 & 41 & 1980 & 66.8 & 2004 & 55.8 \\
1929 & 74.2 & 1953 & 30.8 & 1981 & 59.8 & 2005 & 91.8 \\
1930 & 83.4 & 1954 & 55 & 1982 & 77 & 2006 & 83.6 \\
1931 & 79.1 & 1955 & 68.8 & 1984 & 101 & 2007 & 45.4 \\
1932 & 57.2 & 1956 & 50.5 & 1985 & 44 & 2008 & 65.6 \\
1933 & 64.6 & 1957 & 61 & 1986 & 58.6 & 2009 & 51 \\
1934 & 71.4 & 1958 & 51 & 1987 & 68.4 & 2010 & 78 \\
1935 & 67.8 & 1959 & 51.5 & 1988 & 62.6 & 2011 & 37.2 \\
1936 & 59.8 & 1960 & 127.2 & 1989 & 91.4 & 2012 & 131.4 \\
1937 & 74 & 1961 & 76 & 1990 & 78 & 2013 & 104.2 \\
1938 & 33.4 & 1962 & 70 & 1991 & 47.8 & 2014 & 72.4 \\
1939 & 44.8 & 1963 & 52 & 1992 & 60.6 & 2015 & 54.2 \\
1940 & 48 & 1964 & 58.4 & 1993 & 64.4 & 2016 & 76.6 \\
1941 & 44.6 & 1965 & 115.4 & 1994 & 87 & 2017 & 44.8 \\
1942 & 57 & 1966 & 45.4 & 1995 & 51.1 & 2018 & 51.2 \\
1943 & 60.8 & 1968 & 68.2 & 1996 & 78.1 & 2019 & 82.2 \\
\hline
\end{tabular}

Legend:

$$
\begin{aligned}
& t_{a}=1 \text { minute } \\
& t_{a}=1 \text { hour } \\
& t_{a}=1 \text { day }
\end{aligned}
$$

Table 3. Annual maximum rainfall depths (in $\mathrm{mm}$ ) for duration (d) equal to $24 \mathrm{~h}, H_{d=24}$, derived from data characterized by different aggregation times, $t_{a}$. Todi rain gauge station.

\begin{tabular}{cccccccc}
\hline Year & $\boldsymbol{H}_{\boldsymbol{d}=\mathbf{2 4} \boldsymbol{h}}$ & Year & $\boldsymbol{H}_{\boldsymbol{d}=\mathbf{2 4} \boldsymbol{h}}$ & Year & $\boldsymbol{H}_{\boldsymbol{d = 2 4} \boldsymbol{h}}$ & Year & $\boldsymbol{H}_{\boldsymbol{d}=\mathbf{2 4} \boldsymbol{h}}$ \\
\hline 1921 & 69.3 & 1950 & 32 & 1974 & 56.5 & 1998 & 113.2 \\
1922 & 56 & 1951 & 77.3 & 1975 & 65.6 & 1999 & 88.2 \\
1923 & 63.3 & 1952 & 51.4 & 1976 & 51.4 & 2000 & 42.2 \\
1924 & 39.4 & 1953 & 50.2 & 1977 & 41.8 & 2001 & 54.6 \\
1925 & 52.2 & 1954 & 48.2 & 1978 & 74.2 & 2002 & 83.1 \\
1926 & 46.6 & 1955 & 45.8 & 1979 & 53 & 2003 & 41.7 \\
1927 & 50.8 & 1956 & 52.6 & 1980 & 93.6 & 2004 & 47.4 \\
1928 & 61 & 1957 & 48.4 & 1981 & 29 & 2005 & 70.6 \\
1929 & 65 & 1958 & 45 & 1982 & 49.8 & 2006 & 41.1 \\
1930 & 37.2 & 1959 & 57 & 1983 & 63 & 2007 & 36.8 \\
1931 & 38.4 & 1960 & 124 & 1984 & 67.2 & 2008 & 55.6 \\
1932 & 56 & 1961 & 82.8 & 1985 & 43.4 & 2009 & 83.3 \\
1933 & 48.2 & 1962 & 55 & 1986 & 98.6 & 2010 & 65.1 \\
1934 & 69.6 & 1963 & 88.5 & 1987 & 63.2 & 2011 & 37.5 \\
1935 & 140.4 & 1964 & 90.8 & 1988 & 60 & 2012 & 67.5 \\
1936 & 207 & 1965 & 84 & 1989 & 45.8 & 2013 & 45.8 \\
1937 & 80 & 1966 & 42.2 & 1990 & 65.2 & 2014 & 67.9 \\
1938 & 65.8 & 1967 & 64.2 & 1991 & 46.8 & 2015 & 39.5 \\
1939 & 53.2 & 1968 & 97 & 1992 & 50.8 & 2016 & 55.2 \\
1940 & 61.4 & 1969 & 103.4 & 1993 & 84.1 & 2017 & 47.8 \\
1941 & 58 & 1970 & 38.2 & 1994 & 38.8 & 2018 & 44.2 \\
1942 & 47 & 1971 & 36.5 & 1995 & 137.5 & 2019 & 58 \\
1948 & 41.5 & 1972 & 46.6 & 1996 & 47.2 & & \\
1949 & 51 & 1973 & 58 & 1997 & 118.2 & & \\
\hline
\end{tabular}

Legend:

$$
\begin{aligned}
& t_{a}=1 \text { minute } \\
& t_{a}=1 \text { hour } \\
& t_{a}=1 \text { day }
\end{aligned}
$$




\section{Methods}

Each of the selected $H_{d=24 h}$ series, hereinafter referred to as "uncorrected" because they can contain some underestimated values (see also [47]), is used to verify the existence of possible trend produced by climate change. Specifically, we considered the following tests, selected as they are characterized by very different approaches: (1) least-squares linear trend analysis; (2) non-parametrical Mann-Kendall test [49,50]; and (3) Sen's method [51].

The least-squares method uses a straight line in order to fit the given points and it is known as the method of linear or ordinary least squares. This line is found as the best fit from which the sum of squares of the distances from the points is minimized. Equations with certain parameters usually represent the results in this method. The method of least squares actually defines the solution for the minimization of the sum of squares of deviations or the errors in the result of each equation.

The non-parametrical Mann-Kendall test is commonly used in detecting trends of variables in many fields. Statistic $S$ can be calculated by the following:

$$
S=\sum_{k=1}^{n-1} \sum_{j=k+1}^{n} \operatorname{sgn}\left(x_{j}-x_{k}\right)
$$

with:

$$
\operatorname{sgn}\left(x_{j}-x_{k}\right)=\left\{\begin{array}{c}
+1, \text { if }\left(x_{j}-x_{k}\right)>0 \\
0, \text { if }\left(x_{j}-x_{k}\right)=0 \\
-1, \text { if }\left(x_{j}-x_{k}\right)<0
\end{array}\right.
$$

and where $n$ is the length of the sample, $x_{k}$ and $x_{j}$ are from $k=1,2, \ldots, n-1$ and $j=k+1$, $\ldots, n$. If $n$ is bigger than 8 , statistic $S$ approximates to normal distribution. The mean of $S$ is 0 and the variance of $S$ can be acquired as follows:

$$
\operatorname{var}(S)=\frac{n(n-1)(2 n+5)}{18}
$$

Then, the test statistic $Z$ is denoted by:

$$
Z=\left\{\begin{array}{l}
\frac{S-1}{\sqrt{\operatorname{var}(S)}}, \text { if } S>0 \\
0, \text { if } S=0 \\
\frac{S+1}{\sqrt{\operatorname{var}(S)}}, \text { if } S<0
\end{array}\right.
$$

If $Z>0$, it indicates an increasing trend, and vice versa. Given a confidence level $\alpha$, the sequential data would be supposed to experience statistically significant trend if $|Z|>Z(1-\alpha / 2)$, where $Z(1-\alpha / 2)$ is the corresponding value of $P=\alpha / 2$ following the standard normal distribution. In this study, a 0.05 confidence level was used.

Finally, the innovative trend analysis proposed by Sen (2012) is based on a sub-section time series plot on a Cartesian coordinate system. In this method, recently criticized by [52], a time series is divided into two equal parts that are separately sorted in ascending order. Then, the first sub-series is located on the $X$-axis, and the second sub-series is located on the $Y$-axis. If the investigated data are collected on the 1:1 line, then there is no trend. If data fall above the 1:1 line or below the 1:1 line, then an upward trend or a downward trend in the time series, respectively, exists [51].

We note that these three very common tests could be representative to many others. Furthermore, since they are characterized by very different approaches, they could potentially offer different results.

Successively, the above-mentioned tests were repeated on a new version of the same series (hereinafter referred to as "corrected"), where the underestimation error due to the coarse time resolution of historical rainfall data was eliminated/minimized by using an average correction identically applied to all $H_{d}$ values characterized by the same ratio $t_{a} / d$. We note that an alternative correction approach, based on a sophisticated stochas- 
tic method, would produce very similar results with respect to the simple deterministic approach used here [48]. Note that this last result cannot be easily generalized to any other analysis $[10,53,54]$. With the aim of applying the correction, the average underestimation errors, $E_{a \%}$, have been determined through the relations proposed earlier by [47], expressed by:

$$
\begin{gathered}
E_{a \%}=6.14\left(\frac{t_{a}}{d}\right)^{2}+5.69 \frac{t_{a}}{d}[\%] \quad d \leq 30 \mathrm{~min} \\
E_{a \%}=6.7\left(\frac{t_{a}}{d}\right)^{2}+4.72 \frac{t_{a}}{d}[\%] \quad 30 \mathrm{~min}<d<180 \mathrm{~min} \\
E_{a \%}=5.2\left(\frac{t_{a}}{d}\right)^{2}+5.57 \frac{t_{a}}{d}[\%] \quad d \geq 180 \mathrm{~min}
\end{gathered}
$$

\section{Results and Discussion}

As previously mentioned, initially the $H_{d=24} h$ series were corrected through the use of Equation (5c) proposed by [47]. For correction, we could use any of the relationships proposed by [36-46], but there is no reason to assume that this choice could have a significant effect on the results we present. As an example, Table 4 shows the $H_{d=24 h}$ series of the Spoleto station, both in the original version ("uncorrected") and in the "corrected" version.

\begin{tabular}{|c|c|c|c|c|c|c|c|c|}
\hline \multirow[b]{2}{*}{ Year } & \multicolumn{2}{|c|}{$H_{d=24 h}$} & \multirow[b]{2}{*}{ Year } & \multicolumn{2}{|c|}{$H_{d=24 h}$} & \multirow[t]{2}{*}{ Year } & \multicolumn{2}{|c|}{$H_{d=24 h}$} \\
\hline & $\begin{array}{l}\text { "Uncorr." } \\
\text { Series }\end{array}$ & $\begin{array}{l}\text { "Corr." } \\
\text { Series }\end{array}$ & & $\begin{array}{l}\text { "Uncorr." } \\
\text { Series }\end{array}$ & $\begin{array}{l}\text { "Corr." } \\
\text { Series }\end{array}$ & & $\begin{array}{l}\text { "Uncorr." } \\
\text { Series }\end{array}$ & $\begin{array}{l}\text { "Corr." } \\
\text { Series }\end{array}$ \\
\hline 1921 & 70 & 78.4 & 1959 & 70.8 & 79.3 & 1989 & 52 & 52.1 \\
\hline 1922 & 69 & 77.3 & 1960 & 87.3 & 87.5 & 1990 & 99.4 & 99.6 \\
\hline 1923 & 150 & 168.1 & 1961 & 72.1 & 72.3 & 1991 & 61 & 61.1 \\
\hline 1924 & 142 & 159.1 & 1962 & 79.3 & 79.5 & 1992 & 85.6 & 85.8 \\
\hline 1925 & 62 & 69.5 & 1963 & 112 & 112.2 & 1993 & 60.8 & 60.9 \\
\hline 1926 & 60 & 67.2 & 1964 & 113.6 & 113.8 & 1994 & 56.7 & 63.5 \\
\hline 1927 & 58 & 65.0 & 1965 & 104 & 104.2 & 1995 & 58.5 & 65.6 \\
\hline 1928 & 46.5 & 52.1 & 1966 & 52.9 & 53.0 & 1996 & 67.3 & 75.4 \\
\hline 1929 & 70 & 78.4 & 1967 & 82.8 & 83.0 & 1997 & 61 & 68.4 \\
\hline 1930 & 74 & 82.9 & 1968 & 65.6 & 65.7 & 1999 & 73 & 73.2 \\
\hline 1931 & 53 & 59.4 & 1969 & 76 & 76.2 & 2000 & 48.6 & 48.7 \\
\hline 1932 & 60 & 67.2 & 1970 & 38.7 & 38.8 & 2001 & 35.8 & 40.1 \\
\hline 1933 & 70 & 78.4 & 1971 & 61.6 & 61.7 & 2002 & 54.6 & 54.6 \\
\hline 1934 & 68 & 76.2 & 1972 & 51 & 51.1 & 2003 & 33.4 & 33.4 \\
\hline 1935 & 140 & 156.9 & 1973 & 50.4 & 50.5 & 2004 & 43 & 43 \\
\hline 1936 & 95 & 106.5 & 1974 & 42.6 & 42.7 & 2005 & 99.4 & 99.4 \\
\hline 1937 & 73 & 81.8 & 1975 & 107 & 107.2 & 2006 & 42.7 & 42.7 \\
\hline 1939 & 46 & 51.6 & 1976 & 98 & 98.2 & 2007 & 39.1 & 39.1 \\
\hline 1940 & 58.4 & 65.4 & 1977 & 74.3 & 74.5 & 2008 & 45.6 & 45.6 \\
\hline 1941 & 58.3 & 65.3 & 1978 & 54 & 54.1 & 2009 & 73.6 & 73.6 \\
\hline 1949 & 68.4 & 68.5 & 1979 & 48.1 & 53.9 & 2010 & 52.6 & 52.6 \\
\hline 1950 & 62.4 & 62.5 & 1980 & 68.2 & 68.3 & 2011 & 44.8 & 44.8 \\
\hline 1951 & 85 & 85.2 & 1981 & 61.6 & 61.7 & 2012 & 64.6 & 64.6 \\
\hline 1952 & 71.2 & 71.3 & 1982 & 63.2 & 63.3 & 2013 & 66.4 & 66.4 \\
\hline 1953 & 43.4 & 48.6 & 1983 & 58.4 & 58.5 & 2014 & 78.2 & 78.2 \\
\hline 1954 & 56.6 & 63.4 & 1984 & 73 & 73.2 & 2015 & 60.8 & 60.8 \\
\hline 1955 & 56.5 & 63.3 & 1985 & 38.2 & 42.8 & 2016 & 54.4 & 54.4 \\
\hline 1956 & 81 & 81.2 & 1986 & 78.4 & 78.6 & 2017 & 82.8 & 82.8 \\
\hline 1957 & 60.9 & 68.3 & 1987 & 62.6 & 62.7 & 2018 & 79.2 & 79.2 \\
\hline 1958 & 65.2 & 65.3 & 1988 & 36.6 & 36.7 & 2019 & 62 & 62 \\
\hline
\end{tabular}

Table 4. Annual maximum rainfall depths (in mm) for duration (d) equal to $24 \mathrm{~h}, H_{d=24}$, in the original version ("uncorr.") and in the modified version through Equation (5c) ("corr."). Spoleto rain gauge station.

Legend: 
Then, we fitted a least-squares linear trend to the $H_{d=24 h}$ in both versions, "uncorrected" and "corrected", considering all 39 selected stations. For the "uncorrected" $H_{d=24 \mathrm{~h}}$ series, the number of positive least-square linear trends, equal to 23 , outnumbers the negative ones, equal to 16 (see also Table 5). Opposite results were obtained for the "corrected" $H_{d=24} h$ series, as cases with negative least-square linear trends become equal to 27 , whereas the positive ones become 12 .

Table 5. Slope (in mm/year) of the least-squares linear regressions and Mann-Kendall test statistic $Z$ of annual maximum rainfall depths for the selected stations and for duration $24 \mathrm{~h}$, for the "uncorrected" and "corrected" series. For the Mann-Kendall test statistic $Z$, in bold the cases with significant trend.

\begin{tabular}{|c|c|c|c|c|}
\hline \multirow{2}{*}{$\begin{array}{c}\text { Rain Gauge } \\
\text { Station }\end{array}$} & \multicolumn{2}{|c|}{ Linear Trend Slope (mm/year) } & \multicolumn{2}{|c|}{ Mann-Kendall Test Statistic $Z$} \\
\hline & "Uncorrected" Series & "Corrected" Series & “Uncorrected" Series & "Corrected" Series \\
\hline Abeto & 0.0815 & 0.0196 & 0.79 & -1.97 \\
\hline Amelia & -0.0766 & -0.1913 & -0.59 & -1.45 \\
\hline Arrone & 0.0115 & -0.0333 & 0.29 & -0.19 \\
\hline Assisi & -0.0071 & -0.1097 & -0.41 & -1.15 \\
\hline Attigliano & -0.0212 & -0.0716 & -0.30 & -0.82 \\
\hline Bastia Umbra & -0.0211 & -0.1193 & 0.16 & -0.99 \\
\hline Bevagna & -0.0348 & -0.1158 & -0.84 & -1.81 \\
\hline Calvi dell'Umbria & 0.0227 & -0.0977 & 0.68 & -0.12 \\
\hline Cascia & 0.0751 & 0.0115 & 1.56 & 0.69 \\
\hline Castelluccio di Norcia & 0.4293 & 0.4150 & 1.97 & 1.69 \\
\hline Castiglione del Lago & 0.0907 & 0.0129 & 1.79 & 0.03 \\
\hline Città di Castello & 0.0413 & -0.0154 & 0.75 & 0.16 \\
\hline Compignano & 0.1458 & 0.0527 & 1.66 & 0.81 \\
\hline Corciano & -0.0419 & -0.1482 & -0.55 & -1.13 \\
\hline Ficulle & 0.0363 & -0.0271 & 0.31 & -0.04 \\
\hline Foligno & -0.0604 & -0.0059 & 0.34 & -0.64 \\
\hline Gualdo Tadino & 0.0237 & -0.0277 & 0.28 & -0.38 \\
\hline Gubbio & 0.1680 & 0.1114 & 2.16 & 1.25 \\
\hline Lago di Corbara & 0.2500 & 0.1026 & 1.46 & 0.84 \\
\hline Massa Martana & -0.1288 & -0.2280 & -1.54 & -2.48 \\
\hline Monte del Lago & 0.0639 & 0.0157 & 0.04 & -0.64 \\
\hline Monteleone di Spoleto & 0.0347 & -0.0958 & 1.58 & 0.63 \\
\hline Montelovesco & 0.2639 & 0.1857 & 3.11 & 1.95 \\
\hline Narni Scalo & 0.0082 & -0.1076 & -0.32 & -1.21 \\
\hline Nocera Umbra & 0.1103 & 0.0217 & 1.05 & -0.18 \\
\hline Norcia & 0.0490 & -0.0178 & 0.42 & -0.63 \\
\hline Orvieto & 0.0976 & 0.0572 & 1.43 & 0.74 \\
\hline Perugia & -0.1769 & -0.2129 & -1.72 & -1.99 \\
\hline Petrelle & -0.0551 & -0.1604 & 0.22 & -0.91 \\
\hline Pianello & 0.1181 & 0.0428 & 1.76 & 0.83 \\
\hline Ponte Nuovo & 0.0099 & -0.0697 & 1.03 & -0.47 \\
\hline Prodo & -0.0373 & -0.1039 & 0.38 & -0.17 \\
\hline San Gemini & -0.1220 & -0.2188 & -1.60 & -2.36 \\
\hline San Savino & -0.0285 & -0.1172 & -0.97 & -1.97 \\
\hline Sellano & -0.0315 & -0.1575 & -0.30 & -1.22 \\
\hline Spoleto & -0.2171 & -0.3159 & -2.08 & -3.16 \\
\hline Terni & 0.0368 & -0.0522 & 0.63 & -0.13 \\
\hline Todi & -0.0473 & -0.1102 & -0.15 & -1.09 \\
\hline Umbertide & 0.0576 & -0.0083 & 0.58 & -0.15 \\
\hline average & 0.0287 & -0.0485 & 0.39 & -0.50 \\
\hline standard deviation & 0.1190 & 0.1281 & 1.15 & 1.16 \\
\hline
\end{tabular}

Figure 2 shows a comparison between "uncorrected" and "corrected" annual maximum rainfall depths for duration $24 \mathrm{~h}$ regarding Terni station. As can be seen, the "uncorrected" series shows a positive trend, while the "corrected" series linear trend is negative. This is mainly due to the fact that many old $H_{d=24} h$ values were underestimated, 
due to being derived by daily observations, while in the last decades the original $H_{d=24} \mathrm{~h}$ values have been determined without errors by using rainfall data recorded in data-loggers for each tip time associated with a fixed rainfall depth equal to 0.1 or $0.2 \mathrm{~mm}$. Then, from a geometric point of view, if older values increase due to corrections and the most recent ones remain unchanged, the linear regression will be characterized by a decreasing slope.

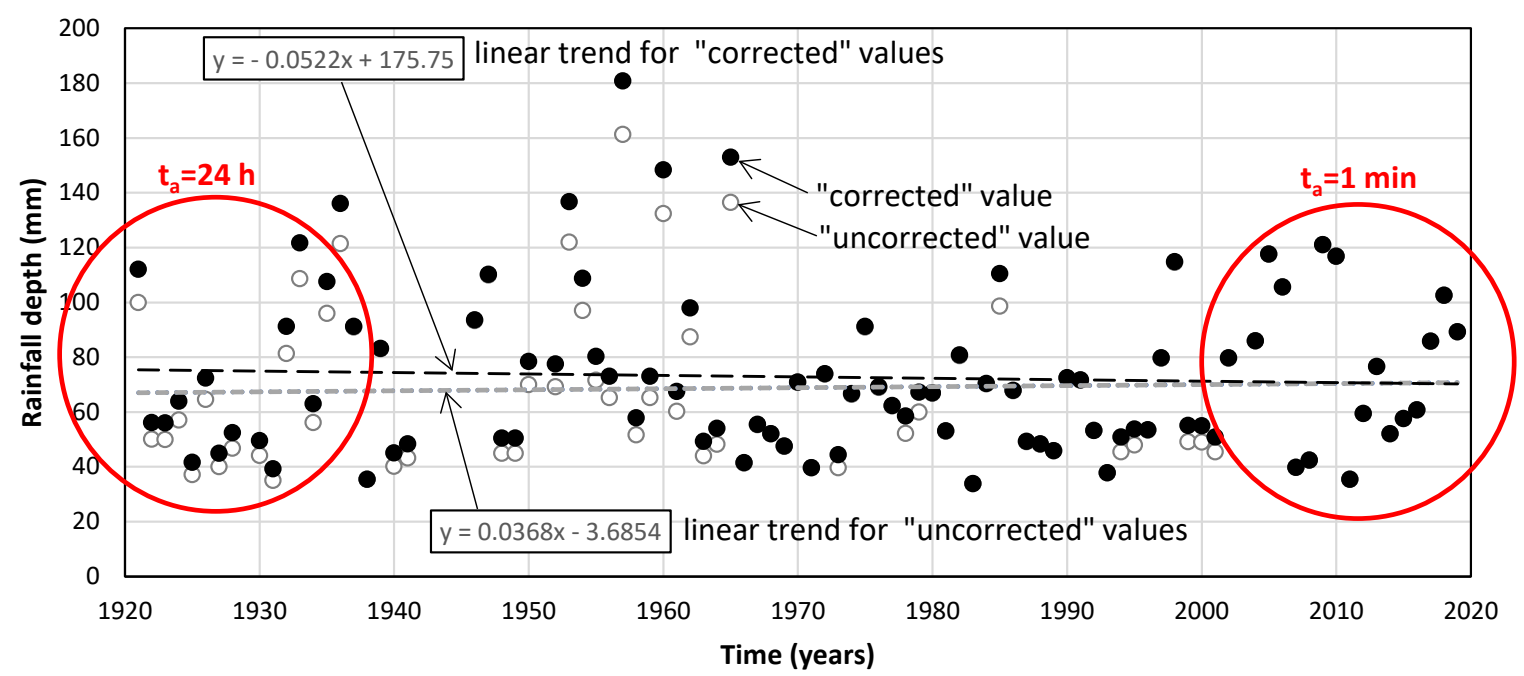

Figure 2. Time sequence of "uncorrected" and "corrected" annual maximum rainfall depths for duration $24 \mathrm{~h}, H_{d=24 h}$, with the respective linear trends, for Terni station. The red circles highlight periods where the $H_{d=24} h$ values have been obtained from rainfall data with the indicated aggregation time, $t_{a}$. During the period 1936-2001 $H_{d=24 h}$ values have been obtained from rainfall data with variable $t_{a}$. Available data within the period 1921-2019.

Figure 3 shows the same comparison of Figure 2 between "uncorrected" and "corrected" $H_{d=24 h}$ series for a restricted number of representative stations. It can be seen that, in some cases, such as that of Figure $3 \mathrm{~h}$ regarding San Savino station, the least-square linear trend was also negative before correction with Equation (5c), with slope of the linear regression equal to $-0.0285 \mathrm{~mm} /$ year. However, after correction, the negative trend becomes exacerbated (slope of the linear regression equal to $-0.1172 \mathrm{~mm} /$ year).

With the main purpose to obtain useful and intuitive graphic representations of the linear trend slopes for both "uncorrected" and "corrected" series, Figure 4 shows the frequency of a reasonable number of slope classes, while in Figure 5 positive and negative slope values have been located in the geographic position of each rain gauge station.

Figure 4 highlights that a Gaussian probability function could be adequate to represent the distribution of linear trend slope values independently if "uncorrected" or "corrected" series are considered, with the average value changing from positive $(0.0287)$ in the case of the "uncorrected" series to negative (-0.0485) for the "corrected" series. As it can also be deduced in Table 5, the two standard deviations are almost indistinguishable.

Figure 5 highlights that, within the Umbria region, there are no geographic areas most affected by specific trends, both when considering the "uncorrected" or "corrected" series.

The analysis of the 39-time series was successively performed by the non-parametric Mann-Kendall test. For the "uncorrected" series, by using a significance level equal to 0.05 , the percentage without significant trends is approximately $90 \%$, with one series (Spoleto) characterized by a significant negative trend, and three series (Castelluccio di Norcia, Gubbio and Montelovesco) by a significant positive trend (see Table 5). After the correction, the Mann-Kendall test evidenced six cases with a significant negative trend (Abeto, Massa Martana, Perugia, San Gemini, San Savino and Spoleto), and no positive cases. Therefore, for the Mann-Kendall test, the transition from "uncorrected" and "corrected" $H_{d=24 h}$ series produces different results and conclusions. 


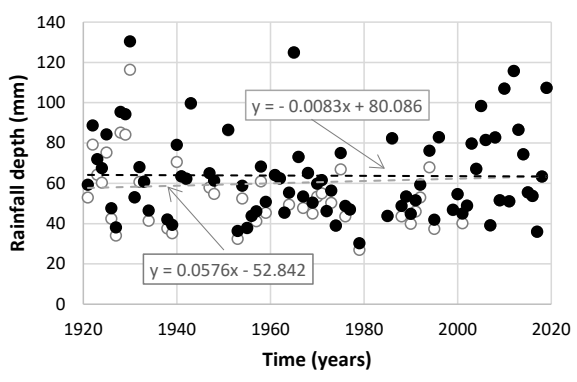

(a)

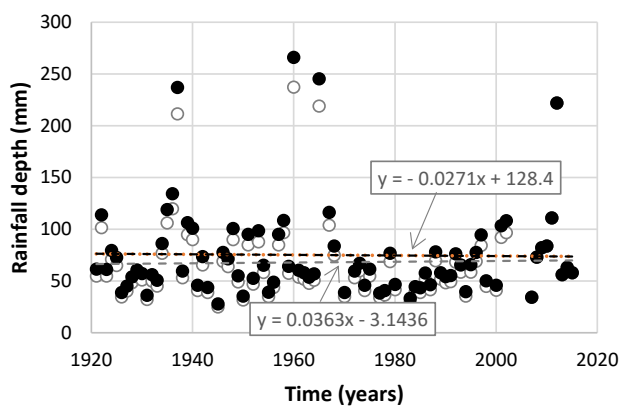

(c)

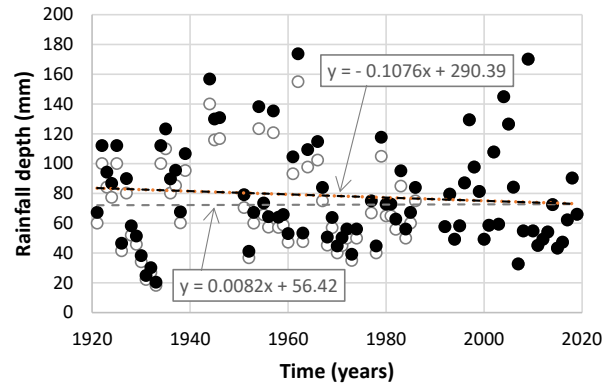

(e)

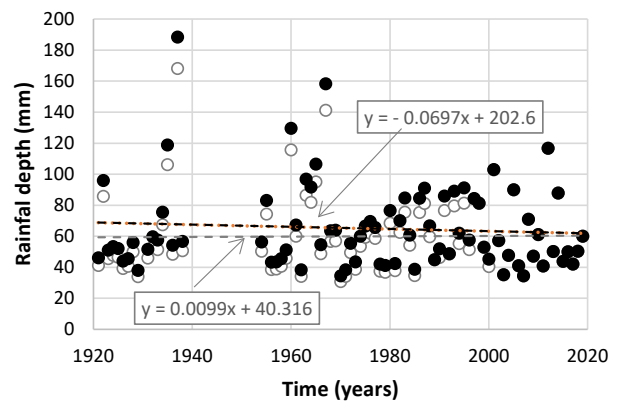

(g)

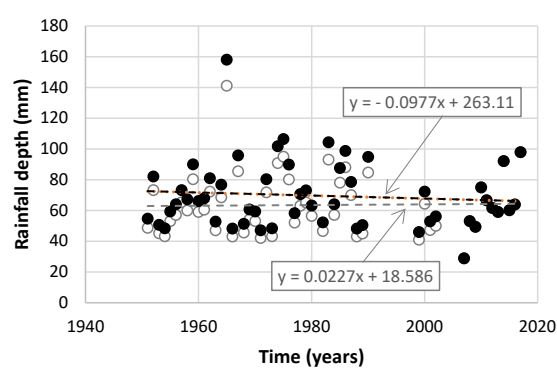

(b)

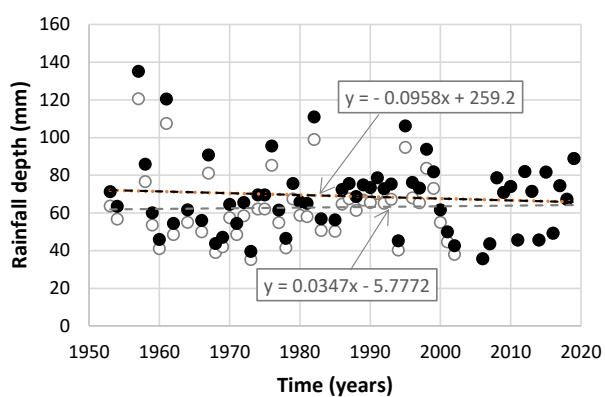

(d)

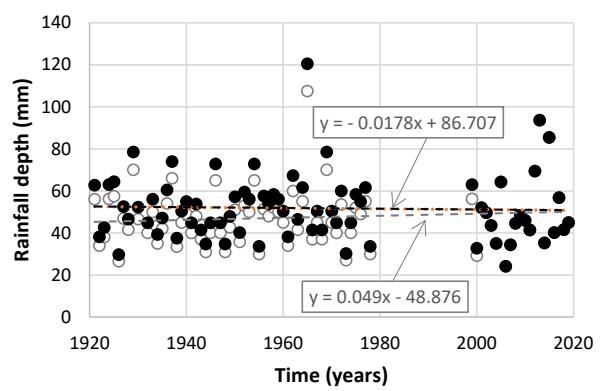

(f)

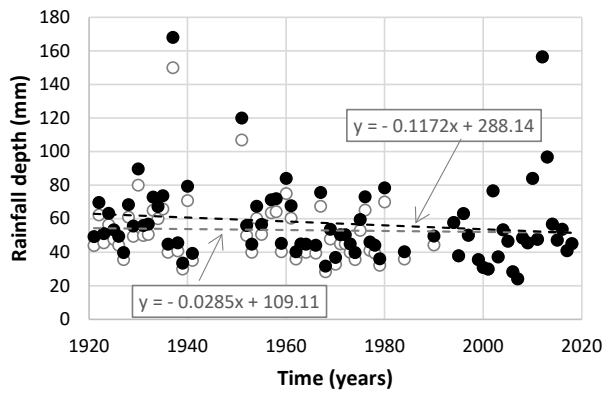

(h)

Figure 3. Time sequence of "uncorrected" and "corrected" annual maximum rainfall depths for duration $24 \mathrm{~h}, H_{d=24} \mathrm{~h}$, with the respective linear trends, for the following stations: (a) Umbertide; (b) Calvi dell'Umbria; (c) Ficulle; (d) Monteleone di Spoleto; (e) Narni Scalo; (f) Norcia; (g) Ponte Nuovo; and (h) San Savino. Available data within the period 1921-2019. 


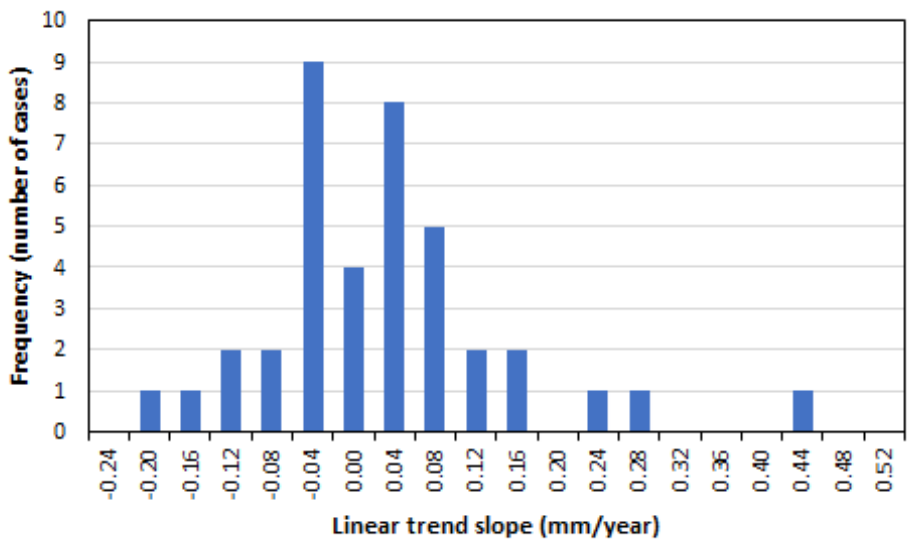

(a)

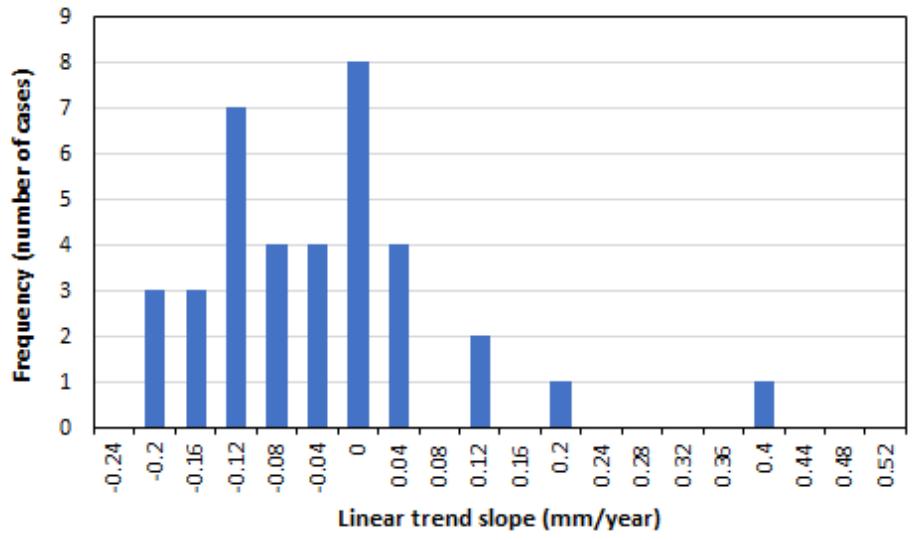

(b)

Figure 4. Frequency of the linear trend slope for (a) "uncorrected" and (b) "corrected" $H_{d=24 h}$ series considering classes amplitude equal to $0.04 \mathrm{~mm} /$ year. All selected rain gauge stations were considered.

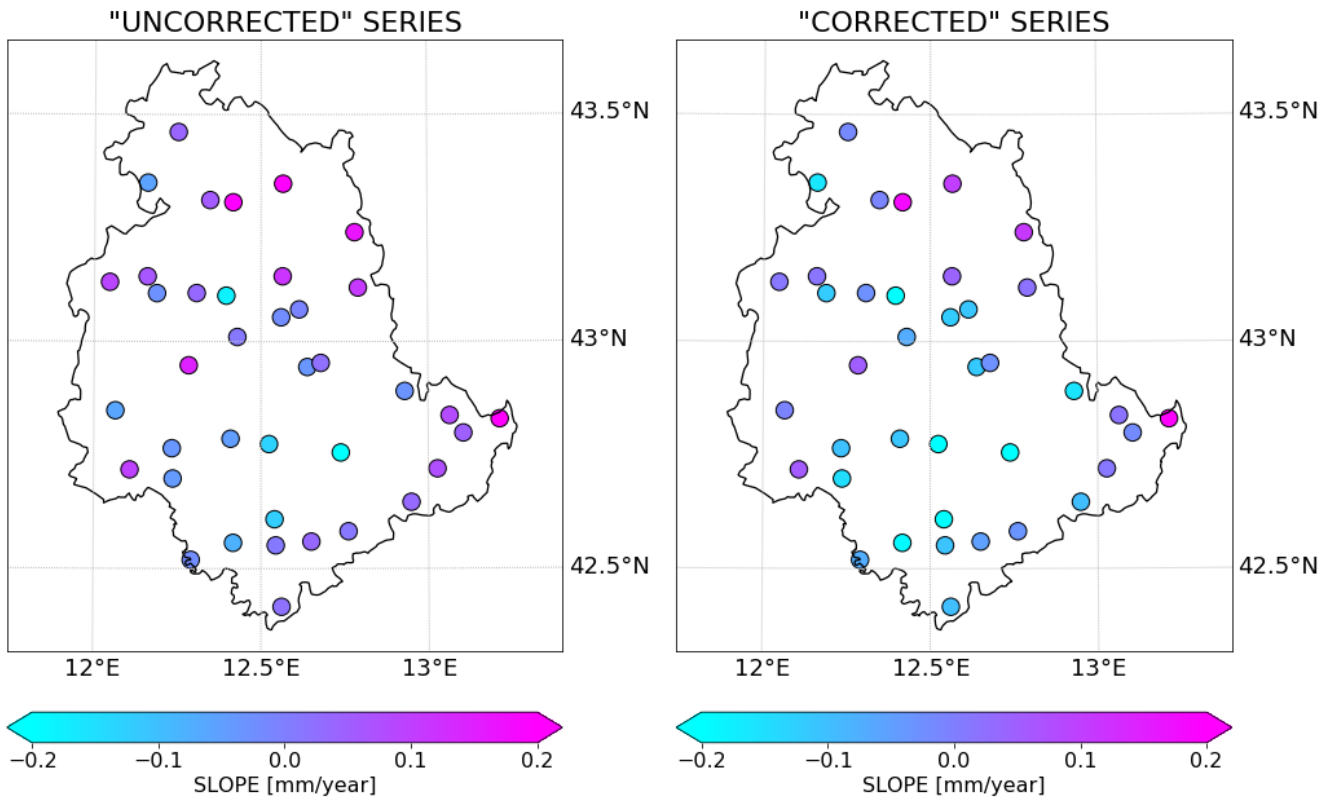

Figure 5. Values of the linear trend slopes for both "uncorrected" (left) and "corrected" (right) $H_{d=24 h}$ series located in the corresponding geographic position of the rain gauge station. 
Similarly to that which has already emerged using the most classic analyses, Sen's method also produces different results when applied to the "uncorrected" and "corrected" annual maximum rainfall depths series. As an example, Figure 6 shows the results of the method for both the "uncorrected" and "corrected" $H_{d=24 h}$ series observed at San Savino station. As can be seen in Figure 6a, the "uncorrected" series shows a no trend condition, because all values are close to 1:1 line and cross it several times, while in Figure $6 \mathrm{~b}$, the "correct" series evidences a clear monotonic decreasing trend (details on the results interpretation can be found in [51]).

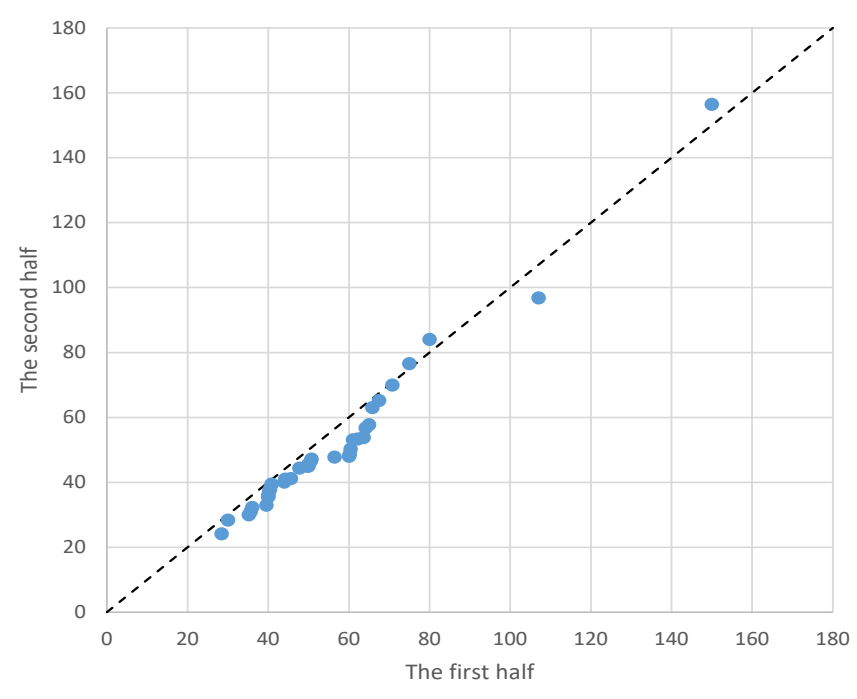

(a)

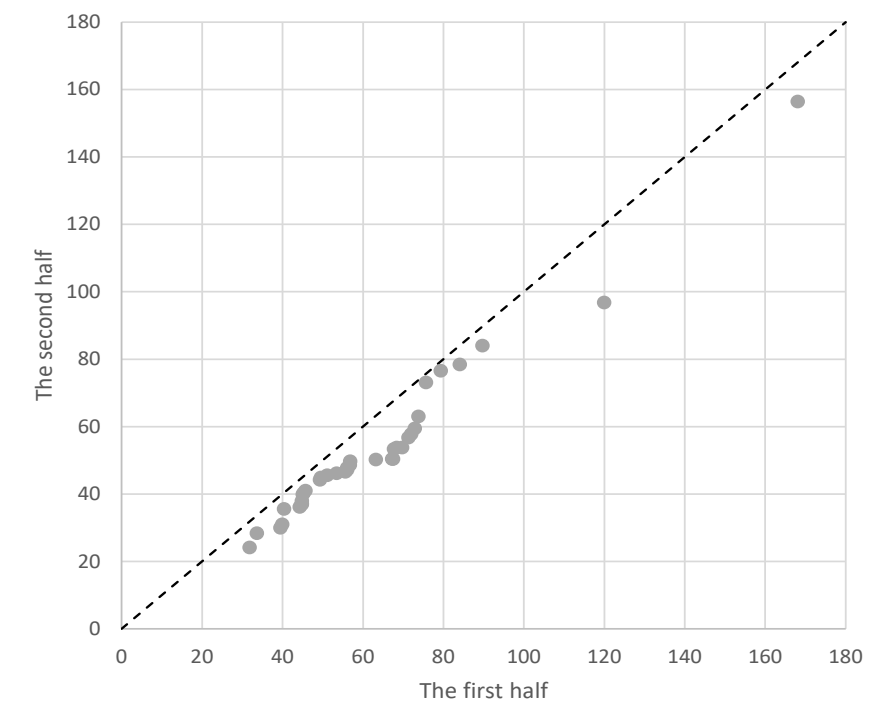

(b)

Figure 6. Trend conditions according to Sen's method for the annual maximum rainfall depths for San Savino station and duration equal to 24 h: (a) "uncorrected" series; and (b) "corrected" series. Available data within the period 1921-2018.

It is interesting to note Sen's method appears less sensitive to the $H_{d}$ underestimation, due to the rainfall coarse temporal aggregation than classical linear regression and MannKendall methods. This depends by the graphical approach on which the method is based. The example of the series regarding Norcia station is emblematic. Moving from the 
"uncorrected" series to the "corrected" series, both the linear trend slope and the MannKendall test statistic $Z$ change from positive to negative values (see Table 5). Instead, as shown in Figure 7, Sen's method suggests that both "uncorrected" and "corrected" series are non-monotonically increasing.

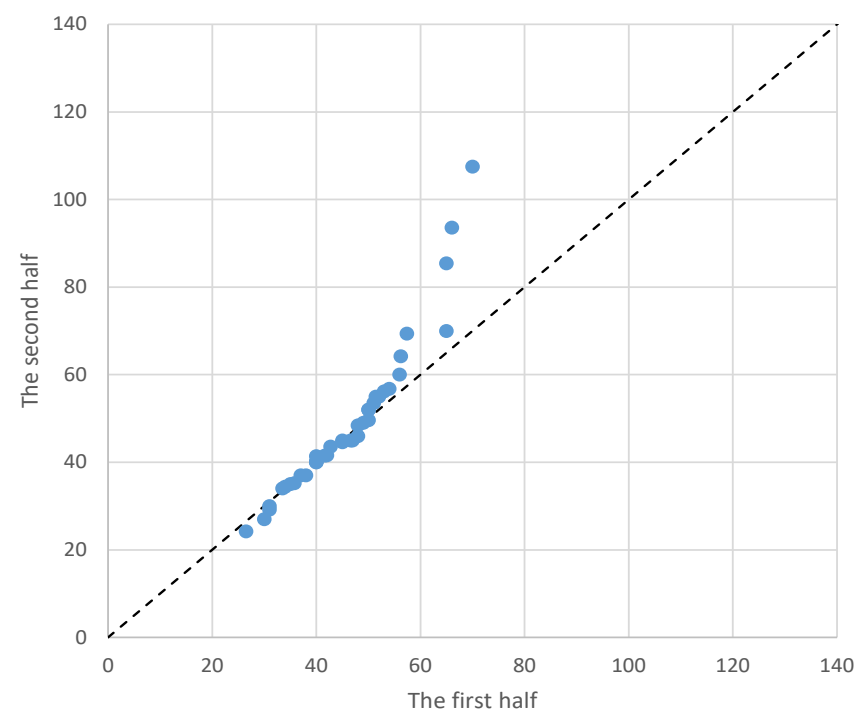

(a)

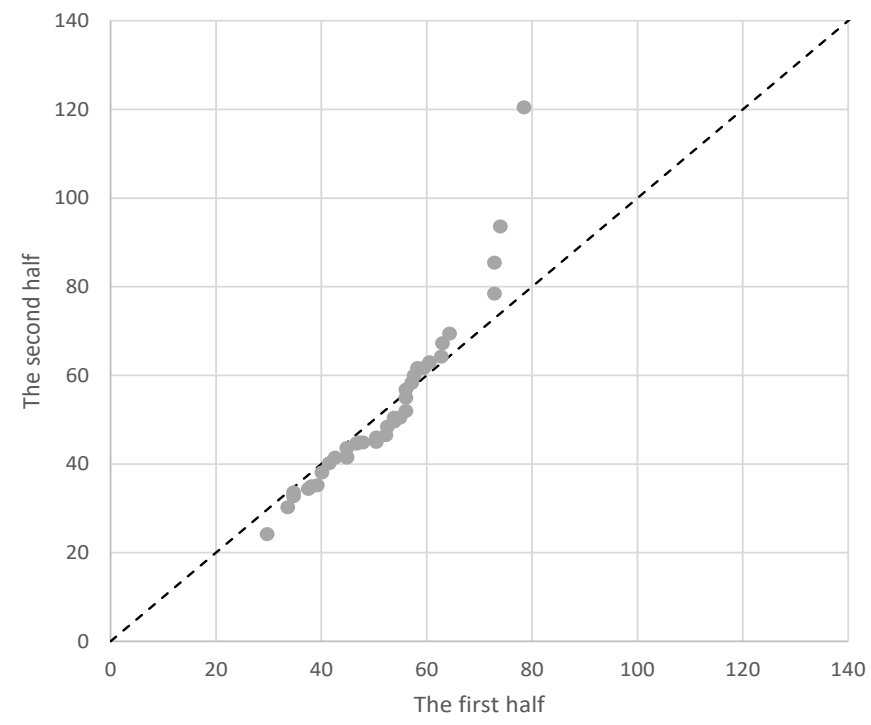

(b)

Figure 7. Trend conditions according to Sen's method for the annual maximum rainfall depths for Norcia station and duration equal to $24 \mathrm{~h}$ : (a) "uncorrected" series; and (b) "corrected" series. Available data within the period 1921-2019.

All the results we have presented refer to a region of central Italy. We believe that they can be generalized to any other geographical area of the world, since it is widely demonstrated that the problem of the $H_{d}$ underestimation is dependent on the technological evolution of rainfall recording systems, with all places showing similarity. In any case, we hope that this work can stimulate other case studies.

Even outside of the scope of this paper, it can be stated that, recently, in a study region located in central Italy, extreme rainfall events characterized by duration $24 \mathrm{~h}$ have not 
clearly and significantly deviated to trends observed 50-80 years ago. Therefore, despite in this region the effects of climate change having produced a continuous decrease in the annual rainfall amount and a significant increase of annual and monthly air temperature, these proclamations that try to attribute to climatic changes also the responsibility for the worrying hydrological and geological instability of the regional territory are not at all justified.

\section{Conclusions}

In the scientific literature, it is possible to find many analyses conducted to assess whether climate change has influenced the trends of the annual maximum rainfall depths with a duration of $24 \mathrm{~h}$. Although it is well known that the $H_{d}$ values obtained from rainfall data characterized by coarse temporal resolution can be significantly underestimated, the aforementioned analyses have been always conducted without taking into account the data origin.

The main objective of this paper was to evaluate the effect of time-resolution of rainfall data on $H_{d=24 h}$ series trend estimation.

A representative number of rain gauge stations working perfectly for approximately a century with available $H_{d=24} h$ series, validated by the Regional Hydrographic Service, was carefully chosen.

All selected series, referred to as "uncorrected" since there were certainly some data containing some underestimated values [47], were used to verify the existence of possible trend due to climate change. For this purpose, we considered the very common leastsquares linear trend analysis, the non-parametrical Mann-Kendall test, and the Sen's method. Successively, the same series were modified through the procedure proposed by [47], with the purpose of eliminating/minimizing the underestimations, obtaining the so-called "corrected" series.

The underestimation errors due to coarse time-resolution of rainfall data produce significant effects on the least-squares linear trend analysis (based on a geometric approach) of the $H_{d=24} h$ values. Specifically, since a prevalence of increasing and decreasing trends for "uncorrected" and "corrected" series, respectively, was observed, the correction procedure can change the sign of the trend. For the non-parametric Mann-Kendall test (based on a statistical approach) with a significance level 0.05 , using the selected 39 "uncorrected" time series, only one case was characterized by a significant negative trend, while three cases exhibited a significant positive trend. After the corrections, cases with negative trends became six, and there were no cases with a positive trend. Finally, the innovative Sen's method (based on a graphical approach) has been noted to be less sensitive to corrections of the $H_{d}$ values than the least-squares linear trend and the Mann-Kendall method. However, its results on the $H_{d=24} h$ series were also affected by the correction.

Overall, it can be concluded that the analysis of $H_{d}$ series containing potentially underestimated values, especially when $d=24 \mathrm{~h}$, can lead to misleading results. Therefore, before conducting any trend analysis, $H_{d}$ values determined from rainfall data characterized by coarse temporal resolution should always be corrected with appropriate procedures suggested by the scientific literature. This correction could be neglected in the analysis performed by using the temporal scale of rainfall records [55].

The analysis conducted in this work may have the limit of considering rainfall data from only one geographical area of the world. There is no reason to assume that choosing only the case study of Umbria instead of many different case studies could have a significant effect on the results we presented. In any case, in the future we hope to find in the scientific literature similar analyses from many other territories.

Author Contributions: Investigation, writing-original draft preparation and writing-review and editing, R.M., C.S., J.D., A.F. All authors have read and agreed to the published version of the manuscript.

Funding: This research was mainly financed by University of Perugia (Fondo Ricerca di Base 2019). 
Informed Consent Statement: Not applicable.

Data Availability Statement: The data presented in this study are available on request from the corresponding author.

Conflicts of Interest: The authors declare no conflict of interest.

\section{References}

1. Koutsoyiannis, D. Revisiting the global hydrological cycle: Is it intensifying? Hydrol. Earth Syst. Sci. 2020, $24,3899-3932$. [CrossRef]

2. Barnett, T.P.; Pierce1, D.W.; Hidalgo, H.G.; Bonfils, C.; Santer, B.D.; Das, T.; Bala, G.; Wood, A.W.; Nozawa, T.; Mirin, A.A.; et al. Human-induced changes in the hydrology of the Western United States. Science 2008, 319, 1080-1083. [CrossRef] [PubMed]

3. Sharafati, A.; Pezeshki, E. A strategy to assess the uncertainty of a climate change impact on extreme hydrological events in the semi-arid Dehbar catchment in Iran. Theor. Appl. Climatol. 2020, 139, 389-402. [CrossRef]

4. Hajani, E. Climate change and its influence on design rainfall at-site in new south wales state, Australia. J. Water Clim. Chang. 2020, 11, 251-269. [CrossRef]

5. Homsi, R.; Sanusi Shiru, M.; Shahid, S.; Ismail, T.; Bin Harun, S.; Al-Ansari, N.; Chau, K.-W.; Mundher Yaseen, Z. Precipitation projection using a CMIP5 GCM ensemble model: A regional investigation of Syria. Eng. Appl. Comp. Fluid Mech. 2020, 14, 90-106. [CrossRef]

6. IPCC. Global Warming of $1.5^{\circ} \mathrm{C}$. An IPCC Special Report on the Impacts of Global Warming of $1.5^{\circ} \mathrm{C}$ above Pre-Industrial Levels and Related Global Greenhouse Gas Emission Pathways, in the Context of Strengthening the Global Response to the Threat of Climate Change, Sustainable Development, and Efforts to Eradicate Poverty; Masson-Delmotte, V., Zhai, P., Pörtner, H.-O., Roberts, D., Skea, J., Shukla, P.R., Pirani, A., Moufouma-Okia, W., Péan, C., Pidcock, R., et al., Eds.; World Meteorological Organization: Geneva, Switzerland, 2018; p. 32.

7. Lenderink, G.; Van Meijgarrd, E. Increase in hourly precipitation extremes beyond expectations from temperature changes. Nat. Geosci. 2008, 1, 511-514. [CrossRef]

8. Hardwick-Jones, R.; Westra, S.; Sharma, A. Observed relationships between extreme sub-daily precipitation, surface temperature, and relative humidity. Geophys. Res. Lett. 2010, 37, L22805. [CrossRef]

9. Wang, J.-W.; Wang, K.; Pielke Sr, R.A.; Lin, J.C.; Matsui, T. Towards a robust test on North America warming trend and precipitable water content increase. Geophys. Res. Lett. 2008, 35, L18804. [CrossRef]

10. Dimitriadis, P.; Koutsoyiannis, D.; Iliopoulou, T.; Papanicolaou, P. A global-scale investigation of stochastic similarities in marginal distribution and dependence structure of key hydrological-cycle processes. Hydrology 2021, 8, 59. [CrossRef]

11. Kunkel, K. North American trends in extreme precipitation. Nat. Hazards 2003, 29, 291-305. [CrossRef]

12. Re, M.; Barros, V.R. Extreme rainfalls in SE South America. Clim. Chang. 2009, 96, 119-136. [CrossRef]

13. Fowler, H.J.; Ali, H. Changes in Extreme Rainfall Events under the Warming Climate. In Rainfall. Modeling, Measurement and Applications; Morbidelli, R., Ed.; Elsevier: Amsterdam, The Netherlands, 2021. [CrossRef]

14. Sun, Q.; Zhang, X.; Zwiers, F.; Westra, S.; Alexander, L.V. A global, continental, and regional analysis of changes in extreme precipitation. J. Clim. 2021, 34, 243-258. [CrossRef]

15. Guerreiro, S.B.; Fowler, H.J.; Barbero, R.; Westra, S.; Lenderink, G.; Blenkinsop, S.; Li, X.F. Detection of continental-scale intensification of hourly rainfall extremes. Nat. Clim. Chang. 2018, 8, 803-807. [CrossRef]

16. Roxy, M.K.; Ghosh, S.; Pathak, A.; Athulya, R.; Mujumdar, M.; Murtugudde, R.; Rajeevan, M. A threefold rise in widespread extreme rain events over central India. Nat. Commun. 2017, 8, 1-11. [CrossRef] [PubMed]

17. Wang, Y.; Zhou, L. Observed trends in extreme precipitation events in China during 1961-2001 and the associated changes in large-scale circulation. Geophys. Res. Lett. 2005, 32, L09707. [CrossRef]

18. Shahid, S. Trends in extreme rainfall events of Bangladesh. Theor. Appl. Climatol. 2011, 104, 489-499. [CrossRef]

19. Park, J.S.; Kang, H.S.; Lee, Y.S.; Kim, M.K. Changes in the extreme daily rainfall in South Korea. Int. J. Climatol. 2011, 31, 2290-2299. [CrossRef]

20. Nkrumah, F.; Vischel, T.; Panthou, G.; Klutse, N.A.B.; Adukpo, D.C.; Diedhiou, A. Recent trends in the daily rainfall regime in southern West Africa. Atmosphere 2019, 10, 741. [CrossRef]

21. Donat, M.G.; Alexander, L.V.; Herold, N.; Dittus, A.J. Temperature and precipitation extremes in century-long gridded observations, reanalyses, and atmospheric model simulations. J. Geophys. Res. Atmos. 2016, 121, 11174-11189. [CrossRef]

22. Gershunov, A.; Cayan, D.R. Heavy daily precipitation frequency over the contiguous United States: Sources of climatic variability and seasonal predictability. J. Clim. 2003, 16, 2752-2765. [CrossRef]

23. Schreck, C.J.; Semazzi, F.H.M. Variability of the recent climate of Eastern Africa. Int. J. Climatol. 2004, 24, 681-701. [CrossRef]

24. Grimm, A.M.; Tedeschi, R.G. ENSO and extreme rainfall events in South America. J. Clim. 2009, 22, 1589-1609. [CrossRef]

25. Haylock, M.R.; Peterson, T.C.; Alves, L.M.; Ambrizzi, T.; Anunciação, Y.M.T.; Baez, J.; Barroz, V.R.; Berlato, M.A.; Bidegain, M.; Coronel, G.; et al. Trends in total and extreme South America rainfall in 1960-2000 and links with sea surface temperature. J. Clim. 2006, 19, 1490-1512. [CrossRef]

26. Cayan, D.R.; Redmond, K.T.; Riddle, L.G. ENSO and hydrologic extremes in the western United States. J. Clim. 1999, 12, 2881-2893. [CrossRef] 
27. Gershunov, A. ENSO influence on intraseasonal extreme rainfall and temperature frequencies in the contiguous United States: Implications for long-range predictability. J. Clim. 1998, 11, 3192-3203. [CrossRef]

28. Aryal, S.K.; Bates, B.C.; Campbell, E.P.; Li, Y.; Palmer, M.J.; Viney, N.R. Characterizing and modelling temporal and spatial trends in rainfall extremes. J. Hydromet. 2009, 10, 241-253. [CrossRef]

29. Kamruzzaman, M.; Beecham, S.; Metcalfe, A.V. Non-stationarity in rainfall and temperature in the Murray Darling Basin. Hydrol. Proc. 2011, 25, 1659-1675. [CrossRef]

30. Kendon, E.J.; Blenkinsop, S.; Fowler, H.J. Will changes in short duration precipitation extremes be detectable before daily extremes? J. Clim. 2018, 31. [CrossRef]

31. Willems, P. Adjustment of extreme rainfall statistics accounting for multidecadal climate oscillations. J. Hydrol. 2013, 490, 126-133. [CrossRef]

32. Teegavarapu, R.S.V.; Nayak, A. Evaluation of long-term trends in extreme precipitation: Implications of in-filled historical data use for analysis. J. Hydrol. 2017, 550, 616-634. [CrossRef]

33. Bonaccorso, B.; Cancelliere, A.; Rossi, G. Detecting trends of extreme rainfall series in Sicily. Adv. Geosci. 2005, 2, 7-11. [CrossRef]

34. Fatichi, S.; Caporali, E. A comprehensive analysis of changes in precipitation regime in Tuscany. Int. J. Climatol. 2009, 29, 1883-1893. [CrossRef]

35. Morbidelli, R.; García-Marín, A.P.; Al Mamun, A.; Atiqur, R.M.; Ayuso-Muñoz, J.L.; Bachir Taouti, M.; Baranowski, P.; Bellocchi, G.; Sangüesa-Pool, C.; Bennett, B.; et al. The history of rainfall data time-resolution in different geographical areas of the world. J. Hydrol. 2020, 590, 125258. [CrossRef]

36. Hershfield, D.M.; Wilson, W.T. Generalizing of Rainfall-intensity-frequency Data. IUGG/IAHS Publication No. 43; AIHS. Gen. Ass. Tor. 1958, 1, 499-506.

37. Hershfield, D.M. Rainfall Frequency Atlas of the United States for Durations from 30 Minutes to 24 Hours and Return Periods from 1 to 100 Years; US Weather Bureau Technical Paper N. 40; U.S. Department of Commerce: Washington, DC, USA, 1961.

38. Weiss, L.L. Ratio of true to fixed-interval maximum rainfall. J. Hydraul. Div. 1964, 90, 77-82. [CrossRef]

39. Harihara, P.S.; Tripathi, N. Relationship of the clock-hour to 60-min and the observational day to 1440-min rainfall. Ind. J. Meteorol. Geophys. 1973, 24, 279-282.

40. Natural Environment Research Council. Flood Studies Report; Natural Environmental Research Council: London, UK, 1975.

41. Van Montfort, M.A.J. Sliding maxima. J. Hydrol. 1990, 118, 77-85. [CrossRef]

42. Faiers, G.E.; Grymes, J.M.; Keim, B.D.; Muller, R.A. A re-examination of extreme 24 hour rainfall in Louisiana, USA. Clim. Res. 1994, 4, 25-31. [CrossRef]

43. Van Montfort, M.A.J. Concomitants of the Hershfield factor. J. Hydrol. 1997, 194, 357-365. [CrossRef]

44. Young, C.B.; McEnroe, B.M. Sampling adjustment factors for rainfall recorded at fixed time intervals. J. Hydrol. Eng. 2003, 8, 294-296. [CrossRef]

45. Yoo, C.; Park, M.; Kim, H.J.; Choi, J.; Sin, J.; Jun, C. Classification and evaluation of the documentary-recorded storm events in the Annals of the Choson Dynasty (1392-1910), Korea. J. Hydrol. 2015, 520, 387-396. [CrossRef]

46. Papalexiou, S.M.; Dialynas, Y.G.; Grimaldi, S. Hershfield factor revisited: Correcting annual maximum precipitation. J. Hydrol. 2016, 524, 884-895. [CrossRef]

47. Morbidelli, R.; Saltalippi, C.; Flammini, A.; Cifrodelli, M.; Picciafuoco, T.; Corradini, C.; Casas-Castillo, M.C.; Fowler, H.J.; Wilkinson, S.M. Effect of temporal aggregation on the estimate of annual maximum rainfall depths for the design of hydraulic infrastructure systems. J. Hydrol. 2017, 554, 710-720. [CrossRef]

48. Morbidelli, R.; Saltalippi, C.; Flammini, A.; Corradini, C.; Wilkinson, S.M.; Fowler, H.J. Influence of temporal data aggregation on trend estimation for intense rainfall. Adv. Water. Resour. 2018, 122, 304-316. [CrossRef]

49. Mann, H.B. Nonparametric tests against trend. Econometrica 1945, 13, 46-59. [CrossRef]

50. Kendall, M.G. Rank Correlation Methods; Griffin: London, UK, 1975.

51. Sen, Z. Innovative trend analysis methodology. J. Hydrol. Eng. 2012, 17, 1042-1046. [CrossRef]

52. Serinaldi, F.; Chebana, F.; Kilsby, C.G. Dissecting innovative trend analysis. Stoch. Environ. Res. Risk Assess. 2020, 34, 733-754. [CrossRef]

53. Iliopoulou, T.; Koutsoyiannis, D. Revealing hidden persistence in maximum rainfall records. Hydrol. Sci. J. 2019, 64, 1673-1689. [CrossRef]

54. Iliopoulou, T.; Koutsoyiannis, D. Projecting the future of rainfall extremes: Better classic than trendy. J. Hydrol. 2020, 588. [CrossRef]

55. Koutsoyiannis, D. Stochastics of Hydroclimatic Extremes—A Cool Look at Risk; Kallipos: Athens, Greece, 2021; 333p, ISBN 978-618-85370-0-2. 